\title{
A 1.2 Ma record of glaciation and fluvial discharge from the West European Atlantic margin
}

\author{
S. Toucanne ${ }^{a, b,{ }^{*}}$, S. Zaragosi ${ }^{a}$, J.F. Bourillet ${ }^{b}$, P.L. Gibbard ${ }^{c}$, F. Eynaud $^{a}$, J. Giraudeau ${ }^{a}$, J.L. \\ Turon $^{a}$, M. Cremer ${ }^{a}$, E. Cortijo ${ }^{d}$, P. Martinez ${ }^{a}$ and L. Rossignol ${ }^{a}$ \\ a Université de Bordeaux, UMR 5805, Avenue des Facultés, F-33405 Talence, France \\ ${ }^{\mathrm{b}}$ IFREMER, Laboratoire Environnements Sédimentaires, BP70, 29280 Plouzané, France \\ ${ }^{c}$ Cambridge Quaternary, Department of Geography, University of Cambridge, Cambridge, CB2 3EN, UK \\ d Laboratoire des Sciences du Climat et de l'Environnement LSCE/IPSL (UMR CEA-CNRS-UVSQ 1572), CE \\ Saclay, L'Orme des Merisiers, Bât. 701, 91191 Gif-sur-Yvette cedex, France
}

\begin{abstract}
*: Corresponding author: S. Toucanne, Tel.: +33 29822 4249; fax: +33 29822 4570, email address : Samuel.Toucanne@ifremer.fr
\end{abstract}

\begin{abstract}
:
The correlation of continental sedimentary records with the marine isotope stratigraphy is a challenge of central importance in Quaternary stratigraphy, particularly in Western Europe where long records of glaciation on land areas are particularly rare. Here we demonstrate for the first time the interrelationship of events during the last $1.2 \mathrm{Ma}$ in an ocean-sediment core from the Bay of Biscay (NE Atlantic), SW of the Channel. The identification of discharge variations from tributary river systems to the 'Fleuve Manche' palaeoriver during glacio-eustatic sea-level lowstands demonstrates the correlation of the marine sediment stratigraphy to the expansion and recession of the European icesheets. The amplitude and chronology of European ice-sheet oscillations since the late Early Pleistocene is discussed and our results demonstrate that the first coalescence of the Fennoscandian and British ice-sheets in the North Sea basin ca $450 \mathrm{ka}$ ago caused a profound change in lowstand European drainage alignment. This change caused a rerouting of Fennoscandian and eastern British ice-sheets-derived meltwaters from northwards into the Nordic Seas to southwards into the eastern North Atlantic thereafter. Besides allowing a thorough synchronisation of the European ice-sheet palaeogeography with the well-dated records of palaeoceanographical changes, our results improve the stratigraphy of the English Channel palaeovalleys and will provide important constraints on paleoclimatic scenarios considering the impact that such rerouting and meltwater surges might have on the stability of the oceanic conveyor belt.
\end{abstract}




\section{INTRODUCTION}

While sea-level reconstructions and the marine $\delta^{18} \mathrm{O}$ record allow the determination of global ice volume during Pleistocene glaciations (e.g. Shackleton, 1987; Ruddiman et al., 1989; Waelbroeck et al., 2002; Siddall et al., 2003), regional ice volume and extent can only be determined indirectly from continental ice-derived sedimentary sequences (e.g. Sejrup et al., 2000; Ehlers and Gibbard, 2004; Svendsen et al., 2004; Shaw et al., 2006; Ehlers and Gibbard, 2007; Bradwell et al., 2008). However, the combined erosional effects of the successive alternating ice-advances and sea-level changes have resulted in a scarcity of long-term shallow marine and continental sequences. This, combined with the difficulties of dating sedimentary sequences precisely, still hinders the correlation of successive regional glaciations with the marine isotope stratigraphy. The reconstruction of ice-sheet extent during Pleistocene glacial intervals is nevertheless crucial because former ice sheets did not simply react passively to climatic changes. Instead they played an active role by amplifying, pacing and driving local, regional and global climate changes (Clark et al., 1999). This was achieved partially through their ability to reroute continental meltwater runoff, with resultant modification of oceanic circulation and climate, particularly at the southern margins of the North American (Clark et al., 2001; Lopes and Mix, 2009) and European ice-sheets (Toucanne et al., 2009). The advance of Pleistocene ice masses into the Northern European lowlands strongly modified the flow directions of central European rivers (Gibbard, 1988, 1995; Busschers et al., 2008). This included massive southwards discharges of fresh meltwaters through the English Channel (La Manche) when the Fennoscandian and British ice sheets were confluent in the North Sea basin (Toucanne et al., 2009) (Fig. 1). The complex network of palaeovalleys demonstrates that North Sea fluvial systems merged in the English Channel with those of the Somme, Seine, Solent and numerous minor French and British rivers during some Pleistocene eustatic lowstands to form the 'Fleuve Manche' (Channel River) palaeoriver, one of the largest systems that drained the European continent (Larsonneur et al., 1982; Gibbard, 1988; Bourillet et al., 2003; Lericolais et al., 2003; Gupta et al., 2007) (Fig. 1). One such major rerouting event was identified during the early penultimate glacial period, in response to the Saalian Drenthe ice-advance (MIS 6), by the recognition of an 
exceptional influx of terrigenous hemipelagic material directly from the 'Fleuve Manche' coeval with the expected deterioration of Northern Hemisphere ice-sheets ca $150 \mathrm{ka}$ ago (Eynaud et al., 2007; Toucanne et al., 2009). Thus, the further the ice-sheets extended in the North Sea area, the greater the sediment-laden meltwater flowed into the English Channel, particularly during subsequent deglaciation (Toucanne et al., 2009). In this way, apart from providing a continuous record of Earth's climate variability, deep-sea cores from the Bay of Biscay therefore offer an invaluable independent record allowing the comparison of discontinuous continental sequences, and the reconstruction of the freshwater and sediment discharges of the 'Fleuve Manche'. They also offer the possibility of detecting the imprint of surrounding ice-sheet oscillations and attendant modification of hinterland drainage directions (Zaragosi et al., 2001; Mojtahid et al., 2005; Ménot et al., 2006; Eynaud et al., 2007; Toucanne et al., 2008; Toucanne et al., 2009).

\section{METHODS}

Core MD01-2448 $\left(44^{\circ} 46.79^{\prime} \mathrm{N}, 11^{\circ} 16.47^{\prime} \mathrm{S}, 3460 \mathrm{~m}\right.$ water depth, 28.8 metre long), recovered from the Charcot deep-seamount (Bay of Biscay) (Fig. 1), is ideally-located to record both the terrigenous supplies from the 'Fleuve Manche' and the amplitude of European glaciation since MIS 35, i.e. during the past 1.2 million years. Although today, as during previous interglacial periods, biogenic sedimentation dominates at this site, Toucanne et al. (2009) demonstrate that terrigenous sediment from the distal part of hypopycnal sediment-laden plumes was deposited here during glacial sea-level lowstands from 'Fleuve Manche' discharges (Fig. 2). This is well supported by the parallel evolution of the terrigenous supplies at site MD01-2448 to those directly from the 'Fleuve Manche' (sites MD95-2002 and MD03-2692, Fig. 1) over the last four glacial periods (Toucanne et al., 2009). Terrigenous supplies at site MD01-2448 were estimated using the XRF-derived ratio of Titanium (Ti) versus Calcium $(\mathrm{Ca})$, largely considered as a proxy for fluvially-derived terrigenous input (e.g. Jennerjahn et al., 2004; Toucanne et al., 2009), and classically quantified via mass accumulation rates (MAR, $\mathrm{g} \mathrm{cm}^{-2} \mathrm{kyr}^{-1}$, see 
Toucanne et al. (2009) for details) (Fig. 3), after correction for coring artefacts (Figs. 2 and 4). Indeed, the detailed observation of the sediment reveals that stretching occurs predominantly in the upper nine metre of the core (i.e. MIS 1 to MIS 8 according to the chronostratigraphic framework) (Figs. 2 and 4). This probably results from cable rebound causing upward piston acceleration (e.g. Skinner and McCave, 2003; Bourillet et al., 2007). Correction of coring artefacts were performed using the CINEMA software (IFREMER, Woerther and Bourillet, 2005; Le Breton, 2006; Bourillet et al., 2007) according to the methodology developed in Toucanne et al. (2009) (Table 1 and Fig. 4). MAR were calculated for each marine isotope stage recognised in the benthic $\delta^{18} \mathrm{O}$ isotopic record (Fig. 3). Stable isotope analyses were undertaken using specimens of benthic foraminifera Uvigerina peregrina and Planulina wuellerstorfi and conducted at the Laboratoire des Sciences du Climat et de l'Environnement (LSCE, Gif-sur-Yvette, France) on both a Finnigan MAT251 and Delta+ mass-spectrometers equipped with a Kiel-device automated introduction line (external reproducibility for standards: 0,05\% ). The chronostratigraphical framework was constructed by synchronising the benthic $\delta^{18} \mathrm{O}$ isotope record to the standard LR04-stack chronology (Lisiecki and Raymo, 2005) (Table 1), and completed by the counting of the planktic polar foraminifera Neogloboquadrina pachyderma (s) (\%) and ice-rafted debris (IRD flux, grains $\mathrm{cm}^{-2} \mathrm{kyr}^{-1}$ ) on the size fraction $>150 \mu \mathrm{m}$ (Fig. 3). All these proxies reveal that the MD01-2448 core allows a continuous long-term reconstruction of sediment-transfer variability from the NW European margin, and provides an unequalled record of palaeoenvironmental changes in Europe through the last $1.2 \mathrm{Ma}$, a period encompassing the transition from the 41-kyr to $100-\mathrm{kyr}$ glacial oscillations, known as the 'mid-Pleistocene transition' (MPT, from ca 1250 to $700 \mathrm{ka}$ according to Clark et al. 2006). 


\section{RESULTS AND DISCUSSION}

1. Sedimentological imprint of the 'mid-Pleistocene transition' in the Bay of Biscay: evidence for the onset of glaciations in Europe

Mean MAR reconstructed for each of the last 35 marine isotope stages reveal a long-term increase of glacial terrigenous supplies at the core site over the last 1.2 Ma (Fig. 3). Prior to $800 \mathrm{ka}$, glacial intervals show MAR of ca $0.5 \mathrm{~g} \mathrm{~cm}^{-2} \mathrm{kyr}^{-1}$, while past $450 \mathrm{ka}$, cold periods experienced much higher rates up to $2.0 \mathrm{~g} \mathrm{~cm}^{-2} \mathrm{kyr}^{-1}$. The intermediate glacial intervals represent a transition between these two end-member situations. Our data demonstrate that during the MPT, the Bay of Biscay experienced a substantial change, not only in sedimentological, but also in climatic conditions. This is revealed by the concomitant glacial sea-surface cooling indicated by the increasing abundance over the period of the planktic polar foraminifera N. pachyderma (s) from 20-30 to $90-100 \%$ during glacial intervals (Fig. 3). This is also indicated by the increase of continental ice volume, and hence of sea-level lowstand conditions, during glacial intervals, as suggested by a global glacial benthic $\delta^{18} \mathrm{O}$ depletion over the period (Fig. 3). The timing of the first significant sedimentological and ecological changes in the Bay around $900 \mathrm{ka}$, i.e. at the height of the MPT when the first significant shift in climate periodicity occurred (Clark et al., 2006), confirms this assumption. It is commonly accepted that sea-level fall and lowstand conditions favoured the seaward transfer of sediment. However, here sea-level fluctuations had a minor impact on the sediment accumulation at site MD01-2448 (Fig. 5 for details) and we assume that core MD01-2448 records the progressive development of extensive Pleistocene ice-sheets over Europe during cold periods. High terrigenous MAR, in the upper part of the record, thus represents the imprint of effective glacial erosion and associated substantial glacial-meltwater discharges (Figs. 3 and 5). From the Middle Pleistocene onwards these events promoted progressive seaward sediment transfer to the Bay of Biscay via the Irish Sea and 'Fleuve Manche'. The European ice-sheets' expansion from mountain to lowland areas thus progressively paralleled the establishment of the 100-ka glacial cycles and contributed, with the Laurentian ice-sheet (Clark and Pollard, 1998; Bintanja and Van De Wal, 2008), to the extensive northern 
hemisphere glaciations, as depicted by the global benthic $\delta^{18} \mathrm{O}$ signal and the increasing IRD flux at site MD01-2448 (Fig. 3). The latter indicates that northern hemisphere glaciers gradually extended to sea level during this transition, allowing icebergs to calve into the North Atlantic (McManus et al., 1999). Moreover, our data suggest that the first significant European ice-sheets developed during MIS 24-22 (ca 930 to $870 \mathrm{ka}$ ), corroborating results obtained by Muttoni et al. (2003) and Haeuselmann et al. (2007) for Alpine valley glaciers in Italy and Switzerland, respectively. This major worldwide glaciation (Shackleton, 1995; Ehlers and Gibbard, 2004), corroborated by a significant sea-level fall (Kitamura and Kawagoe, 2006), was associated with a substantial collapse of the thermohaline circulation, as shown by a strong benthic $\delta^{13} \mathrm{C}$ depletion in the subtropical North Atlantic (Ferretti et al., 2005), as well as at site MD01-2448 (Fig. 3). Typical values of nutrient-enriched southern source water (low $\delta^{13} \mathrm{C}$ up to $-0.5 \%$, Fig. 3) in the Bay of Biscay indeed strongly suggest a diminishing vigor of the northern component of the deep circulation due to the significant extension of northern ice-sheets (McManus et al., 1999; Flower et al., 2000). Contemporaneous high MAR imply that during this period either an ice-sheet covered the British Isles, providing increased terrigenous input to the Bay of Biscay via the Irish Sea, or glacial ice was restricted to Fennoscandia, the 'Fleuve Manche' then funnelling glacial sediment from the southern ice margin to the Bay of Biscay. The question therefore arises as to whether the Bay of Biscay was connected to the North Sea basin at this time? We demonstrate below, that the 'Fleuve Manche' catchment was restricted to the Channel area during MIS 24-22 until the second half of the Middle Pleistocene. This indicates that an ice-sheet probably covered parts of the British Isles ca $900 \mathrm{ky}$ ago. Nevertheless, the low IRD flux at site MD01-2448 indicates that this ice sheet probably did not have extensive calving marine margins, in contrast to those during the last glacial maximum for instance (e.g. Scourse et al., 2000; Peck et al., 2007). The reduced extent of this ice sheet in comparison with the last glacial maximum is also supported by the benthic $\delta^{18} \mathrm{O}$ values during MIS 24-22 which are significantly lighter than during MIS 2 (Fig. 3). 
2. Ice-sheet variability and associated changes of the fluvial drainage network in Europe during the last $500 \mathrm{ka}$

The greatest supplies of terrigenous sediment at site MD01-2448 occurred during MIS 12 and 6 (Fig. 3), the latter correlating with the Saalian Drenthe glaciation (Toucanne et al., 2009) (Fig. 6). This is considered to be the second most extensive Pleistocene glaciation in northern Europe, when ice advanced from centres in northern Russia, Scandinavia and the northern British Isles to cover the North Sea basin (Ehlers and Gibbard, 2004; Svendsen et al., 2004). However, our data indicate that the most extensive event, known as the Elsterian / Anglian glaciation (e.g. Ehlers and Gibbard, 2004), occurred during MIS 12 (Figs. 3 and 6). This correlation ends considerable speculations regarding the equivalence of this glaciation in the marine isotope stratigraphy (e.g. Bowen, 1999; Geyh and Müller, 2005; Gibbard and Van Kolfschoten, 2005; Pawley et al., 2008). The substantially high MAR found during the Elsterian (MIS 12) and subsequently the Saalian (MIS 10-6) and Weichselian (MIS 4-2) stages, in comparison with those from the Early Pleistocene (Fig. 3), indicate, together with the increased volume of the ice-sheet, a profound change of the lowstand European drainage configuration, confirming previous proposals by Gibbard (1988; 1995). Based on our data, and in agreement with paleogeographical reconstructions (Gibbard, 1988; Ehlers et al., 2004; Ehlers and Gibbard, 2004), we conclude that MIS 12 corresponds both to the first time that ice sheets were confluent covering the North Sea basin and that the North Sea-region fluvial system was redirected southwards (Figs. 1 and 6), thus greatly increasing terrigenous supplies to the site MD01-2448 (Fig. 3). This conclusion implies that the British and Fennoscandian ice-sheets remained isolated during previous glaciations, including that preceding the Elsterian, known in the continental stratigraphy as the Donian Stage (Cromerian Complex) glaciation (Fig. 6). The latter occurred during MIS 16, based on our data. On the basis of the evidence presented, the opening of the first connection between the Bay of Biscay and the North Sea occurred in MIS 12. This conclusion independently confirms the timing of the initiation of the Dover Straits which has been previously assigned to this time (e.g. Gibbard, 1988, 1995; Gupta et al., 2007). The direct correlation of this event with the extensive Elsterian glaciation supports the hypothesis of a glacially- 
driven, catastrophic breach of the Weald-Artois structural barrier. This breach occurred following overspill of a massive proglacial lake impounded between the coalescent Fennoscandian and British ice sheets in the central North Sea and the structural barrier across the Dover Strait (Smith, 1985; Gibbard, 1988; Gupta et al., 2007). Here, we assume that the XRF-derived record of $\mathrm{Ti} / \mathrm{Ca}$ ratio potentially depicts this event through the dramatic peak values detected ca $455 \mathrm{ka}$ ago (Fig. 3). From this point onwards, the North Sea drainage, as well as meltwaters that flowed westwards along the southern margin of the Fennoscandian ice-sheet, then drained either into the Bay of Biscay or into the Nordic seas, the courses adopted being dependent upon the ice-sheet location and isostatic adjustment in the North Sea basin, as reported during the early (Drenthe Substage) and late (Warthe) MIS 6 Saalian glaciation, respectively (Toucanne et al., 2009). This assumption requires testing, through sediment chemistry and radiogenic isotope tracers on the terrigenous sediment fraction, for instance. However it almost certainly provides additional constraint on the stratigraphy of the present-day submerged palaeovalleys described from the Dover Strait to the Western Approaches margin (Larsonneur et al., 1982; Bourillet et al., 2003; Lericolais et al., 2003; Gupta et al., 2007).

Reconstructing precisely the alignment of the Rhine and Thames rivers for each of the last five glacial periods is a difficult challenge (Busschers et al., 2007; Toucanne et al., 2009), because of subsequent erosion in the Southern Bight of the North Sea. However, the two-phase incision of the valley systems in the English Channel, recently revealed from high-resolution sonar investigation (Gupta et al., 2007), suggests that only two extreme episodes of meltwater discharges from the southern Fennoscandian ice-margin occurred during the Middle Pleistocene. Based on the MAR and Ti/Ca ratio, these events date to ca $455 \mathrm{ka}$ and $150 \mathrm{ka}$ (Fig. 3). XRF measurements demonstrate, however, that the latter was minor in comparison to that produced by the breach of the Dover Strait and the subsequent catastrophic flood event. Unlike that represented during MIS 12, the seasonal behaviour of the 'Fleuve Manche' runoff ca 150 ka ago, i.e. during MIS 6 (Eynaud et al., 2007; Toucanne et al., 2009), supports the assumption that the discharge was not catastrophic in character. 


\section{Implications and conclusions}

The direct correlation of the European continental glaciation-derived chronology and the marine isotope stratigraphy demonstrated above (Fig. 6), has wider implications, particularly for palaeoclimate reconstructions. Our correlations for the first time allow a synchronisation of the last 1.2 Ma of the European ice-sheet palaeogeography (Ehlers and Gibbard, 2004) with the well-dated palaeoceanographical reconstructions of the North Atlantic (e.g. McManus et al., 1999; Martrat et al., 2007). The confrontation of the European ice-sheet configuration and associated drainage network with the large palaeoceanographical dataset from the European margin could improve the understanding of the ocean-cryosphere interactions, which still remains elusive before the last glacial period. We assume, through the close relationship between freshwater input to the North Atlantic and climate variability (Rahmstorf, 1995; Clark et al., 2001), that during coalescence of the Fennoscandian and British ice sheets the change in drainage direction of the North Sea fluvial system from the Nordic Seas, where North Atlantic Deep Water forms, to the Bay of Biscay could have influenced the thermohaline circulation. Modelling experiments could assist in the evaluation of the impact of such rerouting on the climatic variability detected throughout the Pleistocene glaciations.

\section{ACKNOWLEDGMENTS}

The authors warmly thank A. Tessier, J. Duprat, M.H. Castera and O. Ther for their technical support; K. Cohen, F. Busschers and B. Van Vliet-Lanöe for useful discussions; and Sidney Hemming and an anonymous reviewer, whose comments improved the manuscript significantly We thank also the French Programmes ANR 'IDEGLACE', 'RELIEFS DE LA TERRE' et 'ACTION MARGES' and the Institut Polaire Français Paul Emile Victor (IPEV) for recovery of core MD01-2448; This is UMR 5805 'EPOC' (University Bordeaux 1 - CNRS) contribution $n^{\circ} 1717$. 


\section{TABLE CAPTION}

Table 1: Control points used to tune benthic $\delta^{18} \mathrm{O}$ record of core MD01-2448 to the LR04-stack of Lisiecki and Raymo (2005). Corrected depths correspond to the correction of coring artefacts performed using the CINEMA software. 


\section{FIGURE CAPTION}

Figure 1: Map of NW Europe showing the glacial limits (white shaded areas) of the European ice sheet and Alps glaciers during the maximum Pleistocene ice-advance (Elsterian glaciation), i.e. Marine Isotope Stage 12. White areas over the British Isles and Scandinavia indicate, for comparison, the limits of the British and Fennoscandian ice sheets during the last glacial maximum ca 20-30 ka ago (Ehlers and Gibbard, 2004). The white arrows and the associated lowercase letters identify the main European rivers: $a$ : Fleuve Manche, $b$ : ice-marginal valley (urstromtal), $c$ : Rhine, $d$ : Meuse, $e$ : Thames, $f$ : Solent, $g$ : Somme, $h$ : Seine, $i$ : Loire, $j$ : Gironde. North Sea fluvial systems entering a major proglacial lake in the southern North Sea during the Elsterian glaciation (Cohen et al., 2005). The numbers indicate the core locations: 1: MD01-2448 (this study), 2: MD032692 and 3: MD95-2002 (cited in the text).

Figure 2: Photographs of representative sections (S.) of core MD01-2448. Biogenic (light to white sediment - interglacial) and terrigenous (brown sediment - glacial) sedimentation alternates at site MD01-2448 in phase with climate cycles, as supported at time of glacial-interglacial transition (T.: Termination; MIS: Marine Isotope Stages). Coloured lines under sections indicate the distortion level of the sediment (coring artefacts). Red lines: disturbed sediment (note the bending of laminae = stretching); Green lines: undisturbed sediment (note the planar laminae); Orange line: transition zone from disturbed to undisturbed sediment. Note that the stretching of the sediment strongly decreases within section 6 (early MIS 6, Fig. 4) and is non-existent within section 9, 10 and 16.

Figure 3: Summary of the data obtained from core MD01-2448. (A). Terrigenous Mass Accumulation Rates (MAR, continuous red line; glacial average MAR for MIS 34-14 [0.73 $\left.\mathrm{g} \mathrm{cm}^{-2} \mathrm{kyr}^{-1}\right]$ and MIS 12-2 [1.62 $\left.\mathrm{g} \mathrm{cm}^{-2} \mathrm{kyr}^{-1}\right]$ intervals, dashed red line) and X-ray fluorescence (XRF) Ti/Ca ratio (continuous grey line); (B) Abundance of the polar planktic foraminifera Neogloboquadrina pachyderma senestral (PCHS, red line) and icerafted detritus (IRD) flux (black line); (C) Benthic $\delta^{13} \mathrm{C}$ and (D) $\delta^{18} \mathrm{O}$ for core MD012448 (continuous red line) synchronized onto the LR04 benthic oxygen isotope stack 
(dashed grey line) (Lisiecki and Raymo, 2005). The arrows in the upper and lower part of the figure show the duration of the 'mid-Pleistocene transition' (MPT, from ca 1250 to $700 \mathrm{ka}$ ) according to the definition proposed by Clark et al. (2006). The excellent correlation of the benthic oxygen isotopic curve of core MD01-2448 with the LR04-stack strongly shows the absence of hiatuses in the studied sedimentary record.

Figure 4: Uncorrected (red line) and corrected (green line) sediment accumulation rates (SAR, cm kyr ${ }^{-1}$, terrigenous together with carbonate fraction) at site MD01-2448 over the last 1.2 Ma. SAR, which are necessary to calculate MAR, were calculated for each marine isotope stages (MIS, lowercase numbers) recognised in the benthic $\delta^{18} \mathrm{O}$ isotope record (Fig. 3) according to the MIS boundaries proposed by Lisiecki and Raymo (2005). The stretching prevailing in the upper part (upper nine metre with maximum stretching in the first three meters) of core MD01-2448 then decreasing rapidly, uncorrected and corrected SAR vary mainly in the upper part of the record (MIS 1 to MIS 8) and are closely similar thereafter (MIS 9 to MIS 35). As a result, the evolution of SAR over the last 1.2 Ma, especially the strong increase of SAR detected between ca 800 to $400 \mathrm{ka}$, not resulted from the coring artefact but reflects a significant increase of sediment supply at site MD01-2448. The correction proposed by the CINEMA software is in line with the gradual decrease of the stretching discernible in core MD01-2448 through the detailed analysis of the sediment photographs (Fig. 2). Coloured rectilinear lines in the lower part of the figure indicate the distortion level of the sediment in agreement with the analysis of core sections (S.) presented in Figure 2.

Figure 5: Relationship between Mass Accumulation Rates (MAR) at site MD01-2448 and $\delta^{18} \mathrm{O}$ values from the LR04 benthic oxygen isotope stack (Lisiecki and Raymo, 2005) according to Marine Isotope Stages (MIS, lowercase numbers), glacial (white squares) and interglacial (grey triangles) periods over the last ca $1.2 \mathrm{My}$. This demonstrates, considering the relationship between benthic oxygen isotopic ratio and relative sea-level (RSL) (e.g. Waelbroeck et al., 2002), that terrigenous flux at site MD01-2448 are not significantly influenced by the RSL fluctuations (up to $120 \mathrm{~m}$ ) as demonstrated by (i) the significant dispersion of benthic $\delta^{18} \mathrm{O}$ values for MAR below $1 \mathrm{~g} \mathrm{~cm}^{-2} \mathrm{kyr}^{-1}$; such values 
are described during interglacial (RSL highstand) episodes over the period as well as during glacial (RSL lowstand) intervals preceding MIS 12 (except during MIS 24-22 and MIS 16); (ii) the high dispersion of MAR values in the $\delta^{18} \mathrm{O}$ interval ranging from 4.5 to $5 \%$ which indicate strong differences of MAR at site MD01-2448 while almost similar lowstand conditions prevailed. High MAR described during MIS 24, 22, 16, 12, 10, 8, 6 and 2 probably reflect enhanced sediment transfer to the Bay of Biscay in response to the presence of massive ice-sheets over NW Europe. The ice-sheet forcing is reinforced by the direct relationship between IRD flux (circum-North Atlantic ice-sheet origin) and MAR values (regional origin) at site MD01-2448 (right panel). This show that high terrigenous input in the Bay of Biscay occurred when circum-North Atlantic ice-sheets, including Europe, developed large marine margins, i.e. were particularly extensive. Based on the data presented herein, such a configuration existed mainly during MIS 12, 10, 6 and 2. High MAR at these times also reflect a concomitant profound change of the European drainage network (see text for details).

Figure 6: Correlation between the European continental glaciation-derived chronology (North West European Stages) (Gibbard and Van Kolfschoten, 2005) and the marine isotope stratigraphy (dotted black line: LR-04 stack; continuous red line: benthic $\delta^{18} \mathrm{O}$ for core MD01-2448; MIS are labelled) based on sedimentary evidence of glaciations (glacial stages in red, used as tie points, see text for details) in Europe from core MD012448. In the later Middle Pleistocene pre-Elsterian period (lower panel), the British and Fennoscandian ice-sheets remained isolated during glacial intervals, and usually restricted to mountainous areas (dashed black line). The exception were the MIS 24-22 and MIS 16 (Donian) glaciations during which the ice sheets (white-shaded areas), although more extensive, remained separated. The British and Fennoscandian ice-sheets were confluent for the first time in the North Sea basin during the Elsterian glaciation (upper panel). This caused a massive proglacial lake to form in the basin, the catastrophic drainage of which caused initial breaching of the Weald-Artois structural barrier ca. 455 ky ago. Subsequently, whenever the European ice-sheets advanced during later glaciations, the North Sea fluvial system could be directed southwards during lowstand conditions. Such a condition certainly occurred during the Saalian (MIS 6, continuous 
black line) and Weichselian (MIS 2, dashed black line) maximum ice-advances. The glacial shoreline is represented by the discontinuous yellow lines. 


\section{REFERENCES}

Bintanja, R., Van De Wal, R. S. W., 2008. North American ice-sheet dynamics and the onset of 100,000-year glacial cycles. Nature 454, 869-872.

Bourillet, J. F., Damy, G., Dussud, L., Sultan, N., Woerther, P., Migeon, S., 2007. Behaviour of a piston corer from accelerometers and new insights on quality of the recovery. Proceedings of the 6th International Offshore Site Investigation and Geotechnics Conference: Confronting New Challenges and Sharing Knowledge, 11-13 September 2007, London, UK.

Bourillet, J. F., Reynaud, J. Y., Baltzer, A., Zaragosi, S., 2003. The "Fleuve Manche": the submarine sedimentary features from the outer shelf to the deep-sea fans. Journal of Quaternary Science 18, 261-282.

Bowen, D. Q., 1999. Only four major 100-ka glaciations during the Brunhes Chron? International Journal of Earth Sciences 88, 276-284.

Bradwell, T., Stoker, M. S., Golledge, N. R., Wilson, C. K., Merritt, J. W., Long, D., Everest, J. D., Hestvik, O. B., Stevenson, A. G., Hubbard, A. L., Finlayson, A. G., Mathers, H. E., 2008. The northern sector of the last British Ice Sheet: Maximum extent and demise. Earth-Science Reviews 88, 207-226.

Busschers, F. S., Kasse, C., Van Balen, R. T., Vandenberghe, J., Cohen, K. M., Weerts, H. J. T., Wallinga, J., Johns, C., Cleveringa, P., Bunnik, F. P. M., 2007. Late Pleistocene evolution of the Rhine-Meuse system in the southern North-Sea Basin: Imprints of climate change, sea-level oscillation and glacio-isostacy. Quaternary Science Reviews 26, 3216-3248.

Busschers, F. S., Van Balen, R. T., Cohen, K. M., Kasse, C., Weerts, H. J. T., Wallinga, J., Bunnik, F. P. M., 2008. Response of the Rhine-Meuse fluvial system to Saalian ice-sheet dynamics. Boreas 37, 377-398.

Clark, P. U., Alley, R. B., Pollard, D., 1999. Northern Hemisphere Ice-Sheet Influences on Global Climate Change. Science 286, 1104-1111.

Clark, P. U., Archer, D., Pollard, D., Blum, J. D., Rial, J. A., Brovkin, V., Mix, A. C., Pisias, N. G., Roy, M., 2006. The middle Pleistocene transition: characteristics, mechanisms, and implications for long-term changes in atmospheric $\mathrm{CO} 2$. Quaternary Science Reviews 25, 3150-3184.

Clark, P. U., Marshall, S. J., Clarke, G. K. C., Hostetler, S. W., Licciardi, J. M., Teller, J. T., 2001. Freshwater forcing of abrupt climate change during the last glaciation. Science 293, 283-287.

Clark, P. U., Pollard, D., 1998. Origin of the middle Pleistocene transition by ice sheet erosion of regolith. Paleoceanography 13, 1-9.

Cohen, K. M., Busschers, F. S., Gibbard, P. L., 2005. Stratigraphical implications of an elsterian pro-glacial 'North Sea' lake. In SEQS Subcommission European Quaternary Stratigraphy 2005 annual meeting.(eds Dehnert, A. \& Preusser, F.) Bern, Switzerland.

Ehlers, J., Eissmann, L., Lippstreu, L., Stephan, H. J., Wansa, S., 2004. Pleistocene glaciations of North Germany. In "Developments in Quaternary Science." pp. 135-146. Elsevier.

Ehlers, J., Gibbard, P. L. (2004). "Quaternary Glaciations - Extent and Chronology Part I: Europe." Elsevier, Amsterdam. 
Ehlers, J., Gibbard, P. L., 2007. The extent and chronology of Cenozoic Global Glaciation. Quaternary International 164-165, 6-20.

Eynaud, F., Zaragosi, S., Scourse, J. D., Mojtahid, M., Bourillet, J. F., Hall, I. R., Penaud, A., Locascio, M., Reijonen, A., 2007. Deglacial laminated facies on the NW European continental margin: the hydrographic significance of British Ice sheet deglaciation and Fleuve Manche paleoriver discharges. Geochemistry, Geophysics, Geosystems 8, doi:10.1029/2006GC001496.

Ferretti, P., Shackleton, N. J., Rio, D., Hall, M. A. (2005). Early-Middle Pleistocene deep circulation in the western subtropical Atlantic: Southern hemisphere modulation of the North Atlantic Ocean. In "Geological Society Special Publication." pp. 131-145.

Flower, B. P., Oppo, D. W., McManus, J. F., Venz, K. A., Hodell, D. A., Cullen, J. L., 2000. North Atlantic intermediate to deep water circulation and chemical stratification during the past 1 Myr. Paleoceanography 15, 388-403, doi: 10.1029/1999PA000430.

Geyh, M. A., Müller, H., 2005. Numerical 230Th/U dating and a palynological review of the Holsteinian/Hoxnian interglacial. Quaternary Science Reviews 24, 1861-1872.

Gibbard, P., Van Kolfschoten, T. (2005). "The Pleistocene and Holocene Series." Cambridge University Press, Cambridge.

Gibbard, P. L., 1988. The history of great northwest European rivers during the past three millions years. Phil. Trans. R. Soc. Lond. B318, 559-602.

Gibbard, P. L., 1995. The formation of the Strait of Dover. In: Preece, R.C. (Ed.), Island Britain: a Quaternary Perspective. Geological Society of London Special Publication No. 96, London, 15-26.

Gupta, S., Collier, J. S., Palmer-Felgate, A., Potter, G., 2007. Catastrophic flooding origin of shelf valley systems in the English Channel. Nature 448, 342-345.

Haeuselmann, P., Granger, D. E., Jeannin, P. Y., Lauritzen, S. E., 2007. Abrupt glacial valley incision at $0.8 \mathrm{Ma}$ dated from cave deposits in Switzerland. Geology 35, 143-146.

Jennerjahn, T. C., Ittekkot, V., Arz, H. W., Behling, H., Patzold, J., Wefer, G., 2004. Asynchronous Terrestrial and Marine Signals of Climate Change during Heinrich Events. Science 306, 2236-2239.

Kitamura, A., Kawagoe, T., 2006. Eustatic sea-level change at the Mid-Pleistocene climate transition: new evidence from the shallow-marine sediment record of Japan. Quaternary Science Reviews 25, 323-335.

Larsonneur, C., Auffret, J. P., Smith, A. J., 1982. Carte des paléo-vallées et des bancs de la Manche orientale (1/50 000). BRGM, Brest.

Le Breton, E., 2006. Amélioration de la qualité du carottage Küllenberg. Unpublished Master thesis, Ifremer - Institut National des Sciences Appliquées de Strasbourg, pp. 80.

Lericolais, G., Auffret, J. P., Bourillet, J. F., 2003. The Quaternary Channel River: seismic stratigraphy of its palaeo-valleys and deeps. Journal of Quaternary Science 18, 245-260.

Lisiecki, L. E., Raymo, M. E., 2005. A Pliocene-Pleistocene stack of 57 globally distributed benthic $\mathrm{d}^{18} \mathrm{O}$ records. Paleoceanography 20, PA1003, doi:10.1029/2004PA001071. 
Lopes, C., Mix, A. C., 2009. Pleistocene megafloods in the northeast Pacific. Geology 37, 79-82.

Martrat, B., Grimalt, J. O., Shackleton, N. J., De Abreu, L., Hutterli, M. A., Stocker, T. F., 2007. Four climate cycles of recurring deep and surface water destabilizations on the Iberian margin. Science 317, 502-507.

McManus, J. F., Oppo, D. W., Cullen, J. L., 1999. A 0.5-million-year record of millenialscale climate variability in the North Atlantic. Science 283, 971-975.

Ménot, G., Bard, E., Rostek, F., Weijers, J. W. H., Hopmans, E. C., Schouten, S., Sinninghe Damsté, J. S., 2006. Early reactivation of European Rivers during the last deglaciation. Science 313, 1623-1625.

Mojtahid, M., Eynaud, F., Zaragosi, S., Scourse, J., Bourillet, J. F., Garlan, T., 2005. Palaeoclimatology and palaeohydrography of the glacial stages on Celtic and Armorican margins over the last 360000 yrs. Marine Geology 224, 57-82.

Muttoni, G., Carcano, C., Garzanti, E., Ghielmi, M., Piccin, A., Pini, R., Rogledi, S., Sciunnach, D., 2003. Onset of major Pleistocene glaciations in the Alps. Geology 31, 989-992.

Pawley, S. M., Bailey, R. M., Rose, J. M., Moorlock, B. S. P., Hamblin, R. J. O., Booth, S. J., Lee, J. R., 2008. Age limits on Middle Pleistocene glacial sediments from OSL dating, north Norflok, UK. Quaternary Science Reviews 27, 1363-1377.

Peck, V. L., Hall, I. R., Zahn, R., Grousset, F., Hemming, S. R., Scourse, J. D., 2007. The relationship of Heinrich events and their European precursors over the past $60 \mathrm{ka}$ BP: a multi-proxy ice-rafted debris provenance study in the North East Atlantic. Quaternary Science Reviews 26, 862-875.

Rahmstorf, S., 1995. Bifurcations of the Atlantic thermohaline circulation in response to changes in the hydrological cycle. Nature 378, 145-149.

Ruddiman, W. F., Raymo, M. E., Martinson, D. G., Clement, B. M., Backman, J., 1989. Pleistocene evolution: Northern Hemisphere ice sheets and North Atlantic Ocean. Paleoceanography 4, 353-412.

Scourse, J. D., Hall, I. R., McCave, I. N., Young, J. R., Sugdon, C., 2000. The origin of Heinrich layers: evidence from $\mathrm{H} 2$ for European precursor events. Earth and Planetary Science Letters 182, 187-195.

Sejrup, H. P., Larsen, E., Landvik, J., King, E. L., Haflidason, H., Nesje, A., 2000. Quaternary glaciations in southern Fennoscandia: evidence from southwestern Norway and the northern North Sea region. Quaternary Science Reviews 19, 667685.

Shackleton, N. J., 1987. Oxygen isotopes, ice volume and sea level. Quaternary Science Reviews 6, 183-190.

Shackleton, N. J., 1995. New data on the evolution of Pliocene climatic variability. In: Vrba, E.S., Denton, G.H., Partridge, T.C., Burckle, L.H. (Eds.), Paleoclimate and Evolution. Yale University Press, New Haven, pp. 242-248.

Shaw, J., Piper, D. J. W., Fader, G. B. J., King, E. L., Todd, B. J., Bell, T., Batterson, M. J., Liverman, D. G. E., 2006. A conceptual model of the deglaciation of Atlantic Canada. Quaternary Science Reviews 25, 2059-2081.

Siddall, M., Rohling, E. J., Almogi-Labin, A., Hemleben, C., Meischner, D., Scheizmer, I., Smeed, D. A., 2003. Sea-level fluctuations during the last glacial cycle. Nature $423,853-858$. 
Skinner, L. C., McCave, I. N., 2003. Analysis and modelling of gravity- and piston coring based on soil mechanics. Marine Geology 199, 181-204.

Smith, A. J., 1985. A catastrophic origin for the paleovalley system of the eastern English Channel. Marine Geology 64, 65-75.

Svendsen, J. I., Alexanderson, H., Astakhov, V. I., Demidov, I., Dowdeswell, J. A., Funder, S., Gataullin, V., Henriksen, M., Hjort, C., Houmark-Nielsen, M., Hubberten, H. W., Ingolfsson, O., Jakobsson, M., Kjaer, K. H., Larsen, E., Lokrantz, H., Lunkka, J. P., Lysa, A., Mangerud, J., Matiouchkov, A., Murray, A., Moller, P., Niessen, F., Nikolskaya, O., Polyak, L., Saarnisto, M., Siegert, C., Siegert, M. J., Spielhagen, R. F., Stein, R., 2004. Late Quaternary ice sheet history of northern Eurasia. Quaternary Science Reviews 23, 1229-1271.

Toucanne, S., Zaragosi, S., Bourillet, J. F., Cremer, M., Eynaud, F., Turon, J. L., Fontanier, C., Van Vliet Lanoë, B., Gibbard, P., 2009. Timing of massive 'Fleuve Manche' discharges over the last 350 kyr: insights into the European Ice Sheet oscillations and the European drainage network from MIS 10 to 2. Quaternary Science Reviews 28, 1238-1256.

Toucanne, S., Zaragosi, S., Bourillet, J. F., Naughton, F., Cremer, M., Eynaud, F., Dennielou, B., 2008. Activity of the turbidite levees of the Celtic-armorican margin (Bay of Biscay) during the last 30,000 years: Imprints of the last European deglaciation and Heinrich events. Marine Geology 247, 84-103.

Waelbroeck, C., Labeyrie, L., Michel, E., Duplessy, J. C., McManus, J. F., Lambeck, K., Balbon, E., Labracherie, M., 2002. Sea-level and deep water temperature changes derived from benthic foraminifera isotopic records. Quaternary Science Reviews 21, 295-305.

Woerther, P., Bourillet, J. F., 2005. Exploitation des mesures faites avec les accéléromètres sur le carottier CAPYPSO - Mission SEDICAR - ALIENOR. Ifremer, Brest, TSI/SI/06/10, pp. $47 \& 4$ annexes.

Zaragosi, S., Eynaud, F., Pujol, C., Auffret, G. A., Turon, J. L., Garlan, T., 2001. Initiation of the European deglaciation as recorded in the northwestern Bay of Biscay slope environments (Meriadzek Terrace and Trevelyan Escarpment): a multi-proxy approach. Earth and Planetary Science Letters 188, 493-507. 


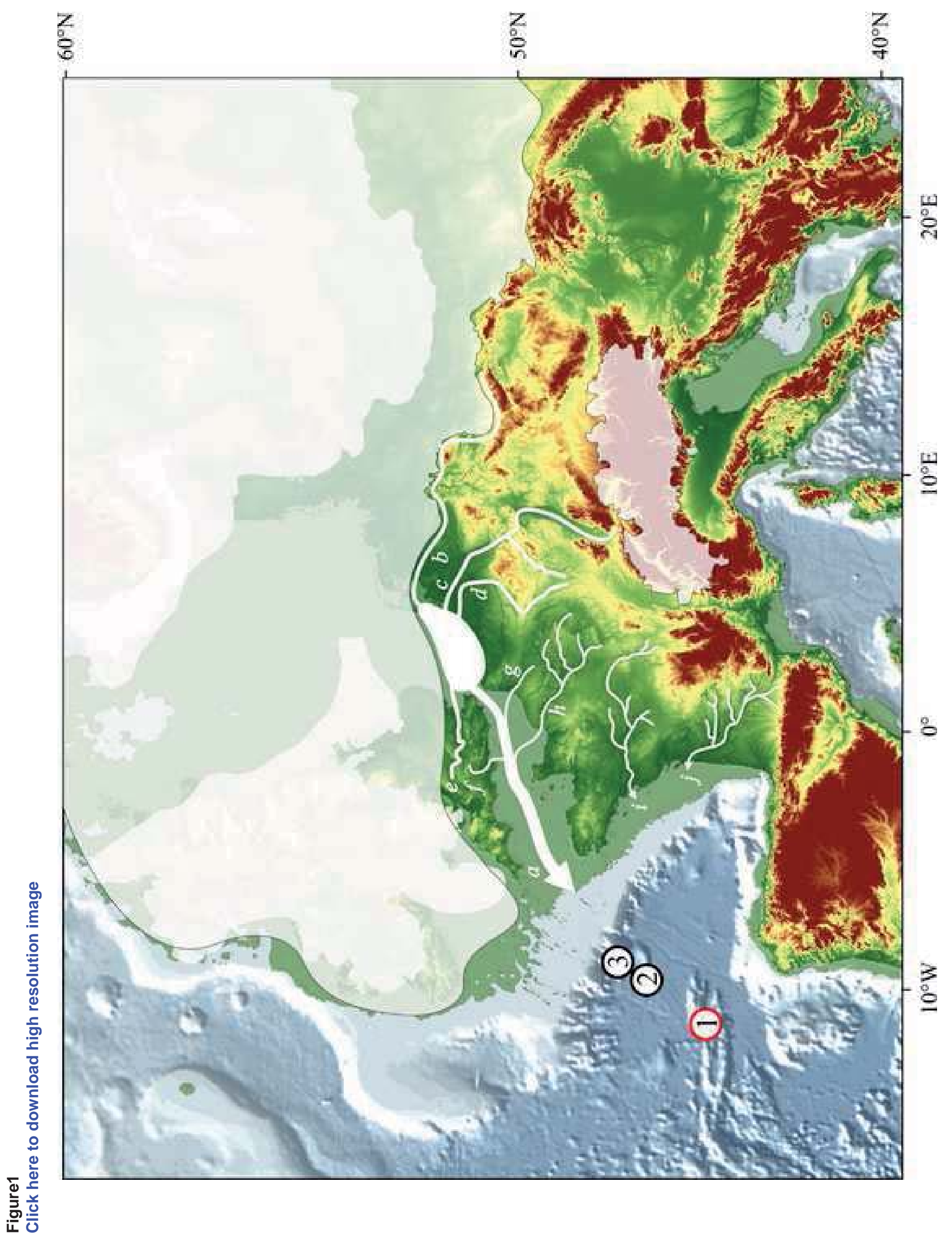




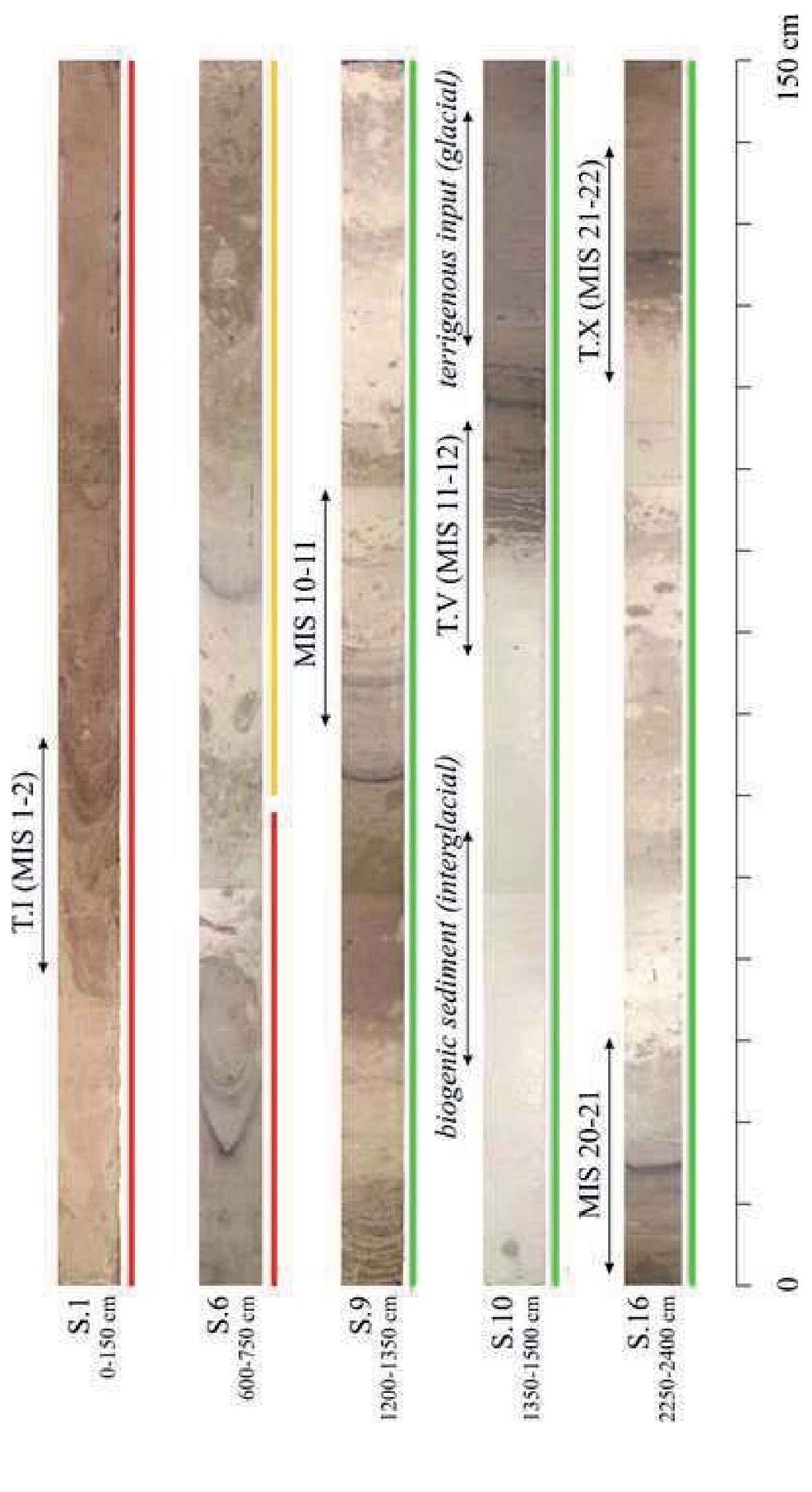



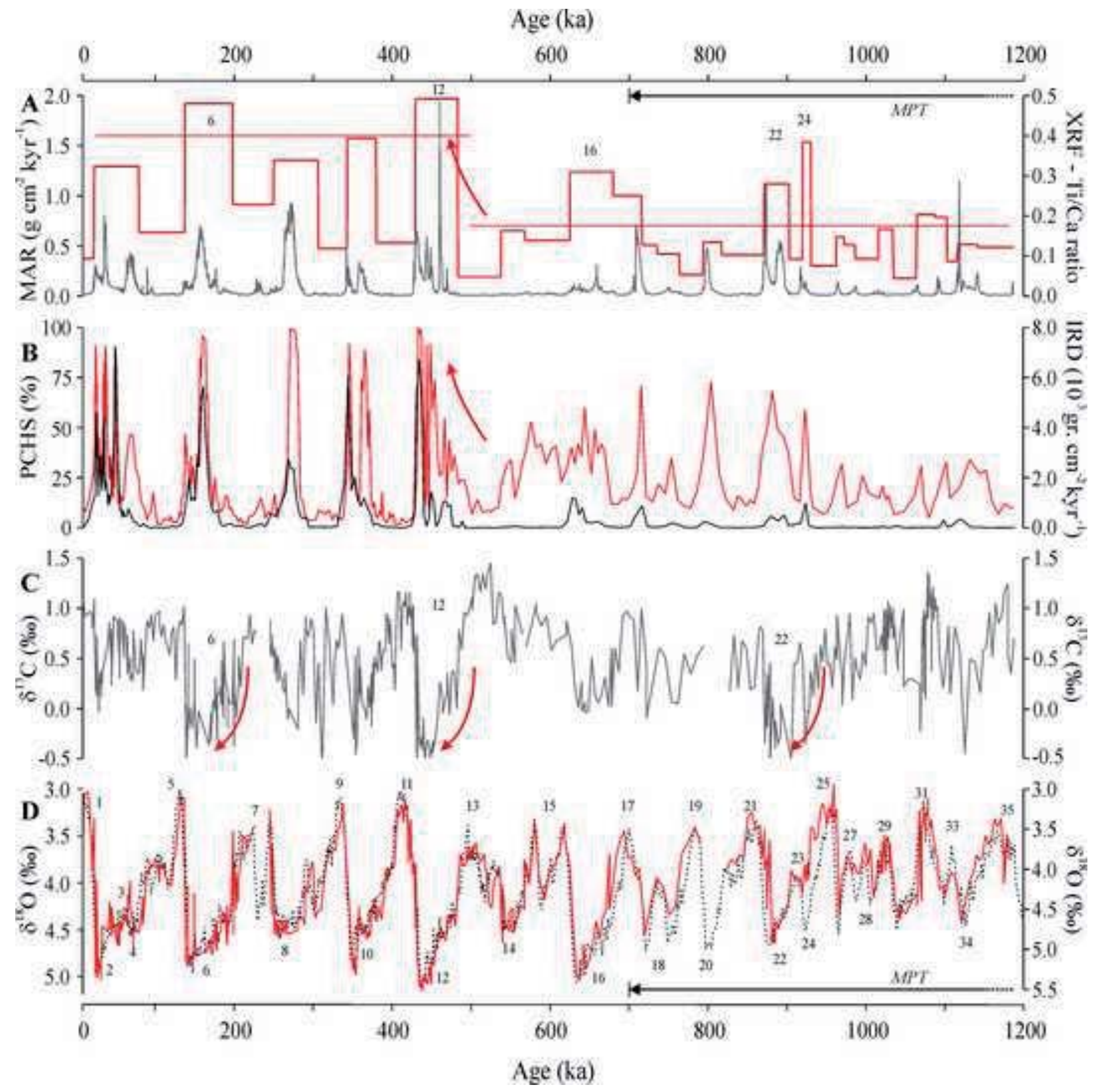


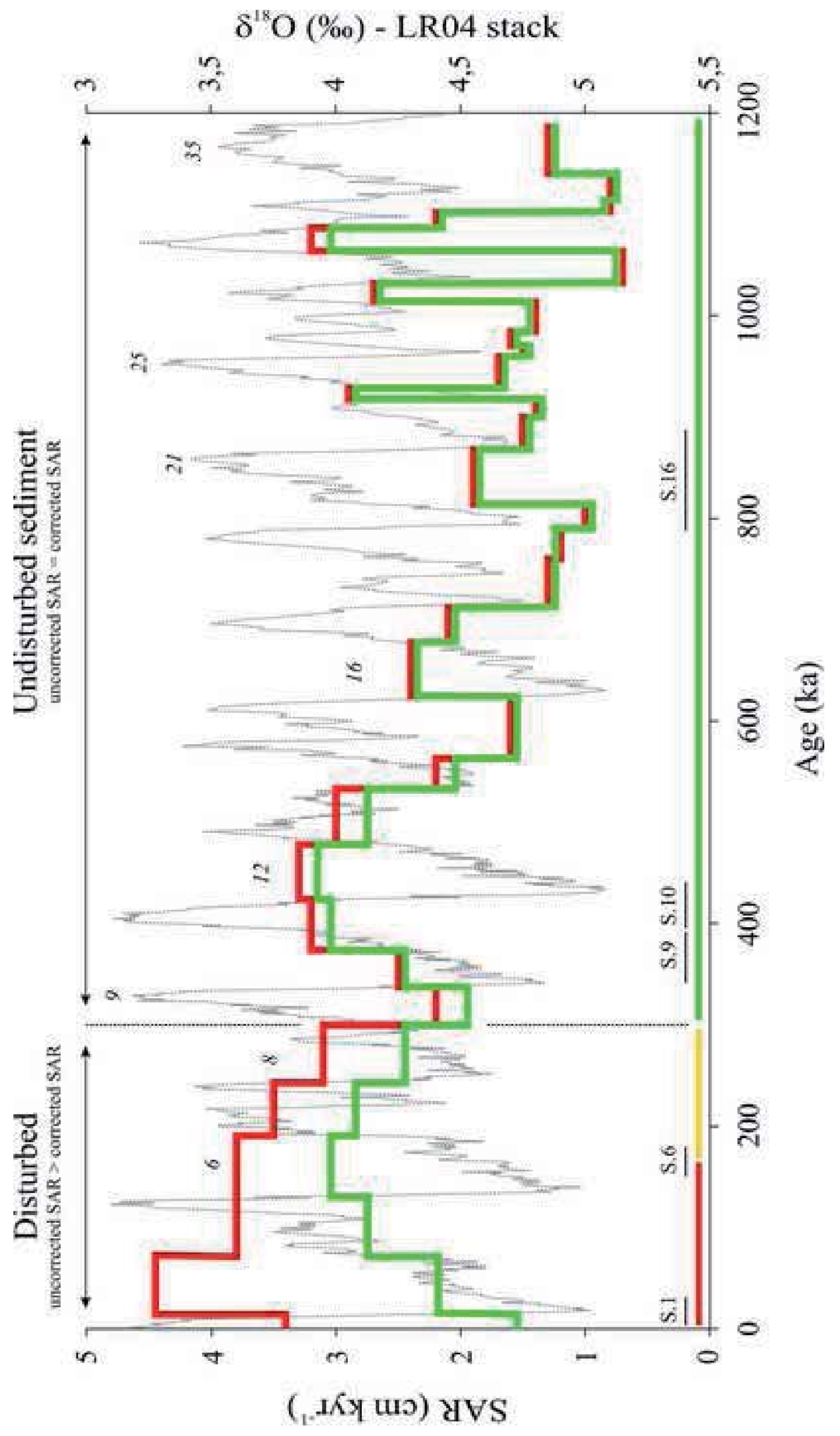




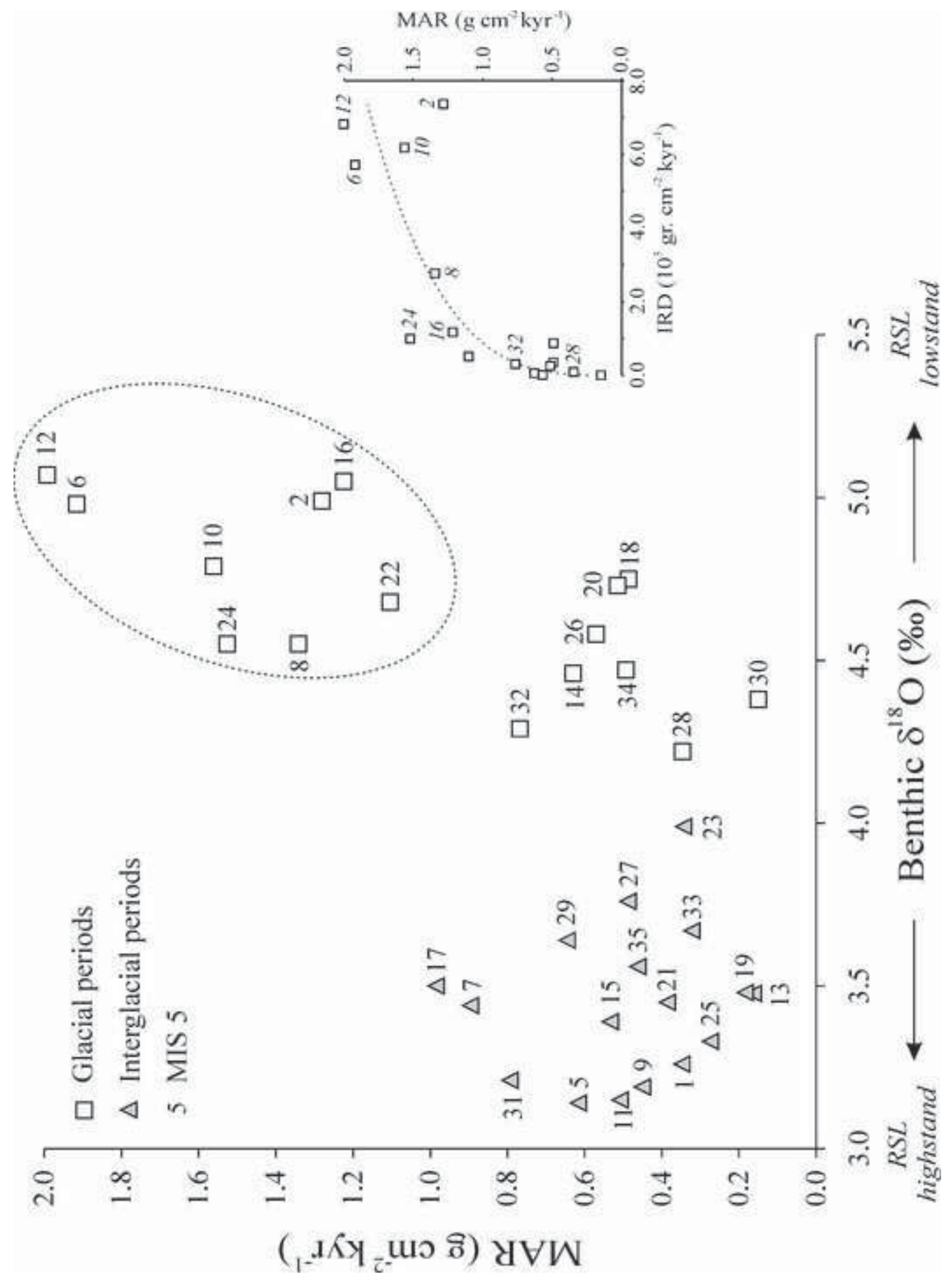




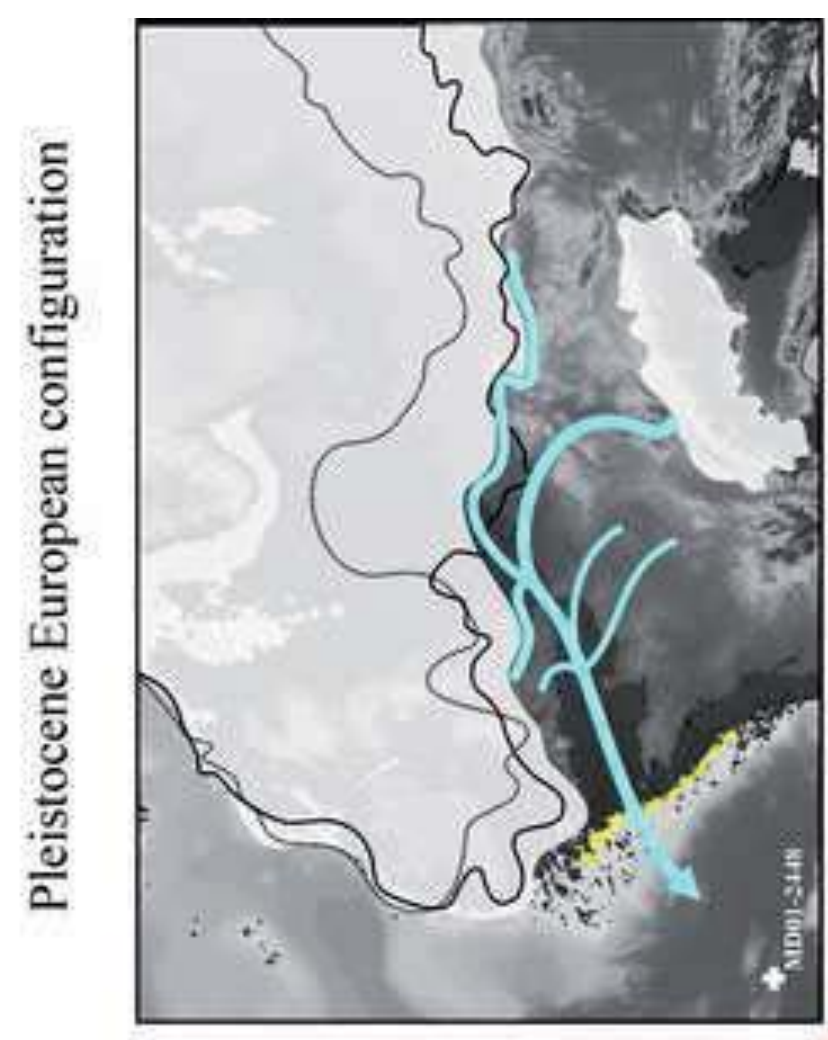

นouมn

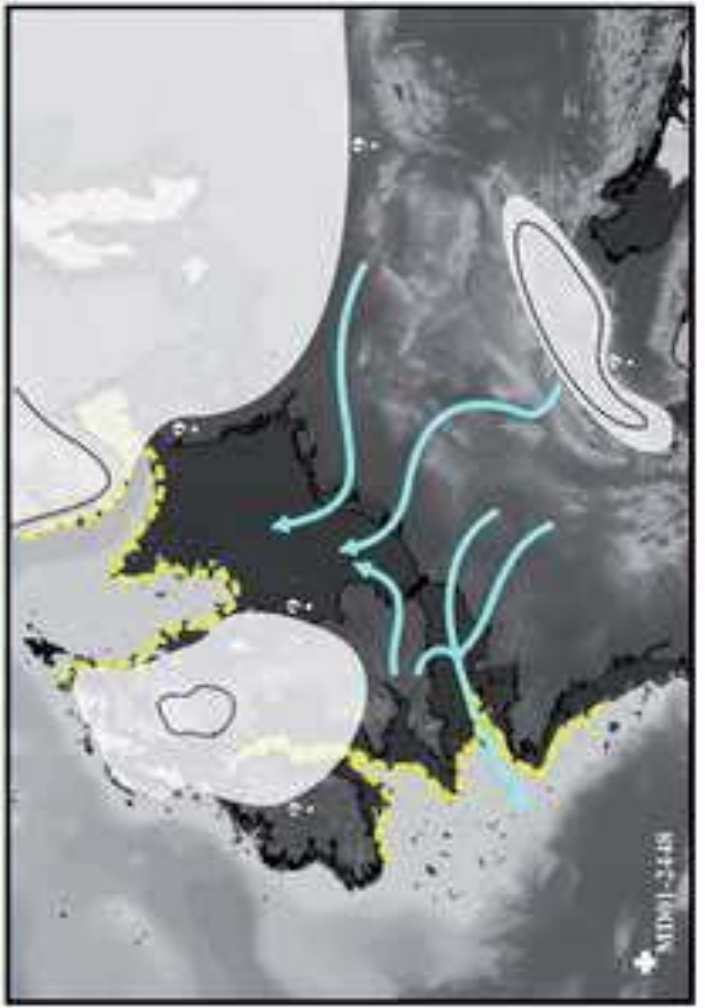

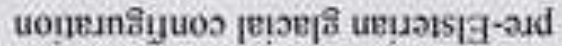

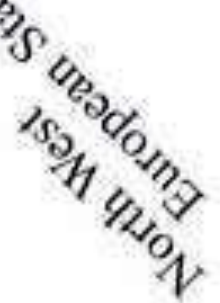

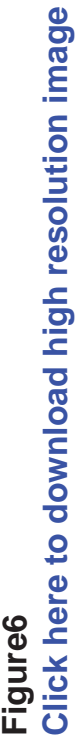

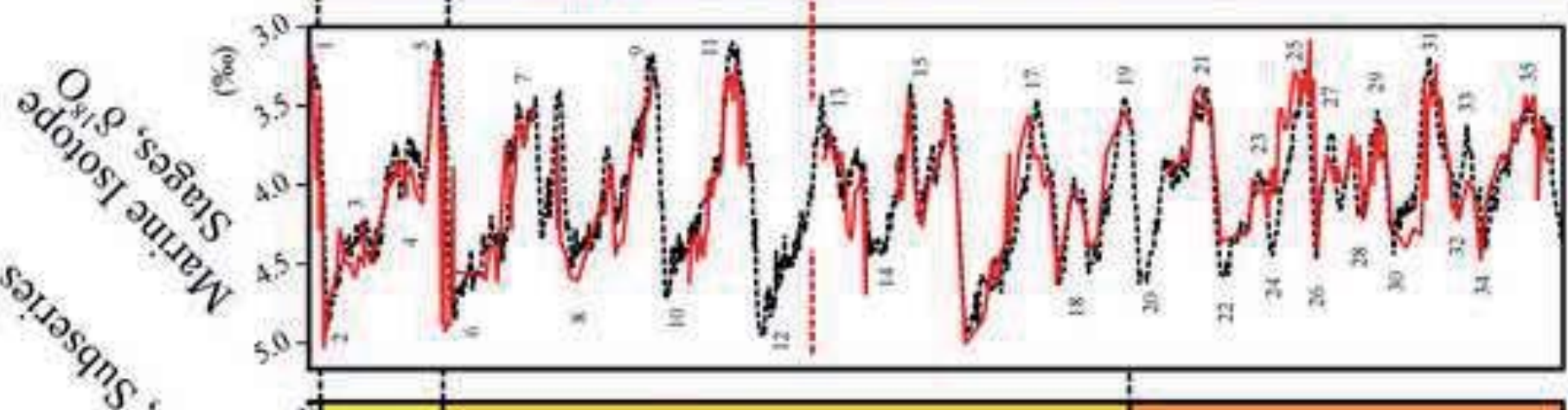
บอบวแน⿰冫)

แอยว คะย

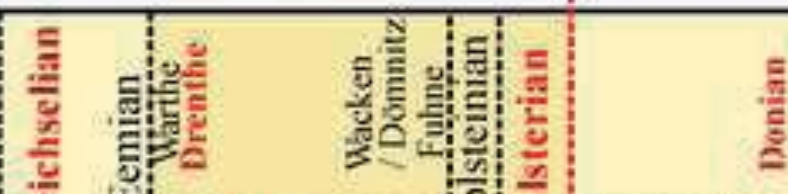

แอยุ|ยล

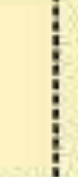




\begin{tabular}{|c|c|c|c|}
\hline Core Label & $\begin{array}{l}\text { depth } \\
(\mathrm{cm})\end{array}$ & $\begin{array}{l}\text { corrected depth } \\
(\mathrm{cm})\end{array}$ & $\begin{array}{l}\text { age (ka) } \\
\text { LR04 stack }\end{array}$ \\
\hline MD01-2448 & 0 & 0 & 0 \\
\hline MD01-2448 & 48 & 22 & 14 \\
\hline MD01-2448 & 300 & 136 & 71 \\
\hline MD01-2448 & 526 & 293 & 130 \\
\hline MD01-2448 & 757 & 478 & 191 \\
\hline MD01-2448 & 938 & 622 & 243 \\
\hline MD01-2448 & 1112 & 761 & 300 \\
\hline MD01-2448 & 1192 & 830 & 337 \\
\hline MD01-2448 & 1284 & 918 & 374 \\
\hline MD01-2448 & 1443 & 1069 & 424 \\
\hline MD01-2448 & 1620 & 1236 & 478 \\
\hline MD01-2448 & 1785 & 1386 & 533 \\
\hline MD01-2448 & 1850 & 1448 & 563 \\
\hline MD01-2448 & 1940 & 1533 & 621 \\
\hline MD01-2448 & 2070 & 1657 & 676 \\
\hline MD01-2448 & 2145 & 1729 & 712 \\
\hline MD01-2448 & 2170 & 1752 & 732 \\
\hline MD01-2448 & 2205 & 1786 & 760 \\
\hline MD01-2448 & 2242 & 1821 & 790 \\
\hline MD01-2448 & 2265 & 1843 & 814 \\
\hline MD01-2448 & 2368 & 1941 & 868 \\
\hline MD01-2448 & 2415 & 1986 & 900 \\
\hline MD01-2448 & 2438 & 2008 & 917 \\
\hline MD01-2448 & 2470 & 2038 & 928 \\
\hline MD01-2448 & 2523 & 2089 & 960 \\
\hline MD01-2448 & 2538 & 2103 & 970 \\
\hline MD01-2448 & 2560 & 2124 & 984 \\
\hline MD01-2448 & 2603 & 2165 & 1014 \\
\hline MD01-2448 & 2653 & 2212 & 1032 \\
\hline MD01-2448 & 2675 & 2233 & 1064 \\
\hline MD01-2448 & 2745 & 2300 & 1086 \\
\hline MD01-2448 & 2780 & 2333 & 1102 \\
\hline MD01-2448 & 2790 & 2343 & 1114 \\
\hline MD01-2448 & 2810 & 2362 & 1140 \\
\hline MD01-2448 & 2874 & 2424 & 1190 \\
\hline
\end{tabular}

